Al Qalam: Jurnal Ilmiah Keagamaan dan Kemasyarakatan

https://jurnal.stiq-amuntai.ac.id/index.php/al-qalam

P-ISSN: 1907-4174; E-ISSN: 2621-0681

DOI : 10.35931/aq.v16i2. 932

\title{
ISLAMIC YOUTH EDUCATION CURRICULUM IN THE QUR'AN
}

\author{
Andri Setiadi ${ }^{1}$, Salman $^{2}$ \\ ${ }^{1}$ Dosen Sekolah Tinggi Ilmu Bahsa Arab Ar-Raayah \\ ${ }^{2}$ Dosen Universitas Muhammadiyah Riau \\ 1andre.setiadi41@gmail.com, ${ }^{2}$ salman@umri.ac.id
}

\begin{abstract}
Youth are agents of change, their existence determines the fate of a nation, whether or not a country will suffer in the future depends on its youth today. This is because youth have more privileges than other age groups. Among these features are the ability of reason and strong body, which has the potential to support the influence he can carry. The brilliance of the Islamic era that we still feel today is a major contribution of Muslim youth in the past. So that what educators have done in the past for their youth is urgent to be studied. Likewise, in the holy book Al-Qur'an, there are many stories of youth, including the story of the youth of Ashabul Kahf, the story of the Prophet Yusuf when he was young and the story of the Prophet Ibrahim when he was young. They are the figures of tough youths who are able to change the society of their time. And when examined further, the success of these youths stems from a straight and true belief in Allah SWT, the strong monotheism in their hearts is what gives great strength and strong motivation in inviting their people to the straight path, namely the way of worshiping Allah alone. .

Keywords: Curriculum, Education, Islamic Youth, Al-Qur'an
\end{abstract}

\section{INTRODUCTION}

The curriculum is etymologically derived from the Latin Curriculum, originally meaning a running course, specially a chariot race course, and in French "Courier" means "to run". To get a formulation about the meaning of curriculum, experts put forward various views. In the classical view, it emphasizes the curriculum as a lesson plan in a school. What lessons and materials must be taken in school, that is the curriculum. In a modern view, the notion of curriculum is more considered as an experience or something that actually happens in the educational process ${ }^{1}$. According to al-Abrasy, the story method is classified as an indirect method of moral education ${ }^{2}$.

\footnotetext{
${ }^{1}$ Nana Syaodih Sukmadinata, Pengembangan Kurikulum (Bandung, 1996).

2 Sultani Dalimunthe, "Metode Kisah dalam Perspektif al-Qur'an,” Jurnal Tarbiyah 23, no. 2 (2016): 276.
}

Al Qalam: Jurnal Ilmiah Keagamaan dan Kemasyarakatan Vol. 16, No. 2

Maret - April 2022 
The story in the Qur'an, its themes, systematics, and methods are not purely artistic. The story of the Koran according to Ayyub Dakhlullah as a means to achieve religious goals. If the story is packaged so that it is easy to read or listen to, without containing lies, then it does not violate religious rules, like most stories in general. If the story contains data and facts, it is usually also known as history. It must be admitted that the story in the Qur'an contains art that is packaged in an interesting way, but is oriented towards Islamic education in shaping the personality of Islamiyah. ${ }^{3}$.

If seen in the book of Mu'jam, the word story with its various musytaqqat (derivatives) is used in the Qur'an 26 times. ${ }^{4}$ The repeated use of this word gives a signal of its urgency to mankind because there are important lessons contained in the stories contained in the Qur'an. In fact, one of the suras (the 28th chapter) in the Qur'an is called Surat al-Qashash, which means stories. Likewise, there are several other letters whose contents contain more stories, such as Yusuf's letter which contains the story of the life of the Prophet Yusuf.

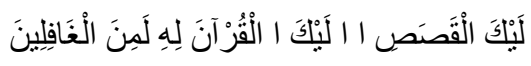

"We tell you the best story by revealing this Quran to you, and indeed you before (We revealed) it were among those who did not know."

If we look at the story in the Koran, it is quite dominant, so that most of the Koran contains stories full of value and wisdom, for example in various letters and verses such as the following;

1. Surah Al-Baqarah presents the story of the search for a golden-yellow female cow to uncover the mystery of criminality by Prophet Musa AS with the permission of Allah.

2. Ali Imran's letter describes the story of the pious Imran family.

3. Yusuf's letter presents the story of the journey of a pious servant of God, from being hurt and expelled to becoming a slave and finally becoming a priest who is obeyed.

4. Surah Al-Isra presents the story of Isra and Mi'raj of the Prophet Muhammad.

5. Surah Al-Kahf presents the story of youth fighters for faith and justice because they were chased by unjust rulers who were finally saved by Allah by sleeping in a cave for more than 300 years; and other similar stories in the letter.

6. Surat Ar-Rum narrates the process of the destruction of the superpowers and the victory of Islam.

7. Surah Noah and Surah Hud tell the story of the prophets who were in preaching and fighting for the mission of Islam.

8. Surah Al-Fil and Surah Al-Quraish which tell the story of God's gift to the Quraysh but instead are misinterpreted by drowning in the life of ignorance.

\footnotetext{
${ }^{3}$ Dalimunthe.

${ }^{4}$ Muhammad Fuad Abdul Baqi, al-Mu'jam al-Mufahras li Alfadz al-Qur'an al-Karim (Cairo: Daar al-Hadists, 2001).
}

Al Qalam: Jurnal Ilmiah Keagamaan dan Kemasyarakatan Vol. 16, No. 2

Maret - April 2022 
9. Surah At-Takatsur which tells the story of rich people who are not satisfied with piling up wealth until death takes them.

10. Surah Al-Lahab which tells the story of Abu Lahab's resistance to the struggle of the Prophet Muhammad SAW

Among the things that can be deduced from the stories contained in the Qur'an is a picture of the firmness of faith when young people are tested with a test of faith. So in this article the author tries to re-examine the stories of youth in the Qur'an to take the values and lessons that can be learned in the context of compiling an Islamic youth education curriculum.

\section{RESEARCH METHODS}

This research is library research using a qualitative approach, namely research that intends to describe a variable, symptom or condition as it is, and is not intended to test certain hypotheses. ${ }^{5}$. Furthermore, to facilitate the collection of data, facts and information that reveal and explain the problems in this research, the authors use the documentation study research method, namely collecting data, facts and information in the form of writings with the help of various materials found in the library room. ${ }^{6}$, for example in the form of hadith books and manuscripts, historical story records; internet and other sources, which are relevant to the study conducted.

\section{RESULTS AND DISCUSSION}

\section{Islamic Education Curriculum}

Curriculum in the traditional view stated that only lesson plans. Whereas in the modern view, the curriculum is more than just a lesson plan or field of study. The curriculum in the modern view is everything that actually happens in the educational process in schools. In other words it is referred to as all learning experiences ${ }^{7}$. This view departs from something that is actual and real at school in the learning process. In education, activities carried out by students can provide learning experiences, such as gardening, sports, scouting and socializing as well as several other activities outside the field of study being studied. They are all rewarding learning experiences. The modern view holds that all learning experiences are the curriculum. On this basis, the core curriculum is experiential learning. It turns out that learning experiences have a lot of influence on the maturation

\footnotetext{
${ }^{5}$ Sugiyono, Metode Penelitian Kuantitatif, Kualitatif dan R and D, 22 ed. (Bandung: Alfabeta, 2016).

${ }^{6}$ A Muri Yusuf, Metode Penelitian Kuantitatif, Kualitatif dan Penelitian Gabungan, 4 ed. (Jakarta: Kencana, 2017).

${ }^{7}$ Ahmad Tafsir, Ilmu Pendidikan Dalam Perspektif Islam (Bandung: Remaja Rosdakarya, 2012).
}

Al Qalam: Jurnal Ilmiah Keagamaan dan Kemasyarakatan Vol. 16, No. 2

Maret - April 2022 
of children, not only studying the subjects of social interaction in the school environment, cooperation in groups, interactions in the physical environment, and others, it is also a learning experience. ${ }^{8}$.

According to Bukhari Umar ${ }^{9}$ Among the functions of the curriculum in Islamic education are as follows:

1. a tool used to achieve goals so that human expectations are in accordance with the aspired goals.

2. Guidelines and programs that must be carried out by subjects and objects of education

3. Continuity function for preparation for the next school level and preparation of workers for those who do not continue

4. Standardization in evaluating the success criteria of an educational process, or as a limitation of program activities that will be carried out on a quarterly, semester, or certain level of education.

To be able to achieve the goals of Islamic education as expected, then of course the material to be presented or discussed as study material is material taken from sources of Islamic teachings. ${ }^{10}$. Therefore, the material is very important in Islamic education because the material is one component in Islamic education. According to Ahmad Tafsir, the material for Islamic education at the time of the Prophet was concerned with: faith education, worship, morality, economics and political bases, including deliberation. ${ }^{11}$.

Meanwhile, according to Hasan al-Bana ${ }^{12}$ In detail, the Islamic education materials include:

1. Faith; This material is considered as the main material in Islamic education, which can be a driving force for the human soul to carry out other practices.

2. Worship; This material is a central theme in the Qur'an and must be learned and applied in everyday life.

3. Morals; This material is an effort to fortify humans/students from human moral decadence in everyday life.

4. Jihad; This material is required as a means to fight for Islam under the influence of Western imperialism, besides that, jihad in a broad sense includes fighting against lust and fighting Satan.

5. Physical; This material is to grow the physical or physical health of humans/students, because the aspect of physical health is very influential on the soul and mind.

From the description above, it can be understood that Islamic education material covers

\footnotetext{
${ }^{8}$ Bukhari Umar, Ilmu Pendidikan Islam (Jakarta: Amzah, 2010).

${ }^{9}$ Umar.h. 172

${ }^{10}$ Badiuzzaman Said Nursi, Iman Kunci Kesempurnaan. Terjemahan dari AlIman wa Takamulul Insan, 1 ed. (Jakarta: Robbani Press, 2004). h. 12

${ }^{11}$ Tafsir, Ilmu Pendidikan Dalam Perspektif Islam. h. 58

${ }^{12}$ A. Fatah Yasin, Dimensi-dimensi Pendidikan Islam (Malang: UIN Malang Press, 2008). h. 124

Al Qalam: Jurnal Ilmiah Keagamaan dan Kemasyarakatan Vol. 16, No. 2

Maret - April 2022
} 
various aspects, both worldly and hereafter. The core material for faith education is monotheism, which is divided into monotheism rubûbiyyah, monotheism ulûhiyyah (ubudiyah), and monotheism asmâ wa character. Tawhid comes from the word wahhada (وَحَّد) which means to unite or not to say. In a syar'i (religious) sense, monotheism is to negate the equality of the Essence of Allah, His attributes, actions, allies and divinity as well as His worship. ${ }^{13}$ As the word of Allah SWT who eliminates equality with Him in Surah al-Ikhlas verses 1-4 which means:

Say: "He is Allah, the One and Only God. Allah is the Lord who depends on Him for all things. He has neither begotten nor begotten. And there is no one equal to Him."

In addition, monotheism has the meaning of believing in the Oneness of Allah SWT in Rubûbiyyah, sincerely worshiping Him, and assigning His names and attributes. ${ }^{14}$ According to Wismanto ${ }^{15}$ Some scholars divide the knowledge of monotheism into three levels, namely monotheism rubûbiyyah, monotheism ulûhiyyah, and monotheism asmâ` wa character.

\section{Tawhid Rubûbiyyah}

SayAl-Rabbcomes from Arabic, Rabba-Yurabbi-Rabban or Tarbiyah which means "educating". ${ }^{16}$ Rubûbiyyah is a word that is attributed to one of the names of Allah SWT, namely "Rabb". This name has several meanings, including: al-Murabbi (maintainer), al-Nâşir (helper), alMalik (owner), al-Mus lih (repair), al-Sayyid (master) and al-Wali ( guardian). In the terminology of Islamic law, the term monotheism rubûbiyyah means believing that only Allah swt. the one and only Creator, Owner, Controller of the universe by whose destiny He turns on and turns off and controls nature with His decrees. ${ }^{17}$ According to Buraikan ${ }^{18}$, monotheism rubûbiyyah includes the following dimensions of faith:

a. Believe in the general deeds of Allah. For example creating, providing sustenance, turning on, turning off, controlling etc.

b. Believe in Allah's destiny.

c. Believe in the essence of God.

Believing in the rubûbiyyah of Allah SWT means believing completely that He is the only Rabb, no partner and no helper for Him. Allah's command. includes the command of the universe 81

${ }^{13}$ Abu Bakar Jabir Al-Jazairi, Aqidah Seorang Mukmin, 1 ed. (Solo: CV. Pustaka Mantiq, 1994). h.

${ }^{14}$ Shalih bin Fauzan Al-Fauzan, Kitab Tauhid I, 1 ed. (Jakarta: Darul Haq, 2011). h. 19

${ }^{15}$ Abu Hasan Wismanto, Kitab Tauhid “Esa-kanlah-Aku” (Pemalang: Nasya Expanding Manajemen, 2016).

${ }^{16}$ Abdurrahman Madjrie, Meluruskan Akidah, 1 ed. (Yogyakarta: Titian Ilahi Press, 1997). H. 83

${ }^{17}$ Ibrahim bin Muhammad Al-Buraikan, Pengantar Studi Aqidah Islam, 1 ed. (Jakarta: Robbani Press, 1998).

${ }^{18}$ Al-Buraikan. H. 142

Al Qalam: Jurnal Ilmiah Keagamaan dan Kemasyarakatan Vol. 16, No. 2

Maret - April 2022 
(kauni) and the commandment of shara' (syar'i). He is the regulator of nature, as well as the breaker of all matters according to the demands of His wisdom. He is also the breaker of the rules of worship and the laws of mu'amalah in accordance with the demands of His wisdom. ${ }^{19}$ In addition, monotheism rubûbiyyah has the meaning that Allah SWT is the only God who has authority over His creatures who govern the entire universe, there are no partners for him in regulating the entire order of this universe. Likewise Allah swt. that governs the course of one's life. Therefore, as believers, we must believe in the monotheism of Allah. Because not a few people claim to believe in Allah SWT. but do not believe in its provisions. Even though everything that happens in this life is a condition. The dimension of monotheism rubûbiyyah consists of faith in angels, apostles, the Day of Judgment, faith in books, and faith in qađa and qadar. The explanation is as follows:

1) Faith in Angels

Angels are creatures created by Allah SWT that originate from light; it cannot be seen or sensed with the five human senses. However, he still exists and carries out the tasks given by Allah SWT. Angels are also creatures created by Allah SWT who never violate Allah's commands. Believing in the existence of angels is one of the conditions to justify one's faith. For a Muslim, having faith in the angels, by believing that the angels are creatures of Allah SWT are very noble. ${ }^{20}$ Thus, believing in angels means believing that Allah SWT has created spirits called angels whose nature and work are different from humans and live in another world (unseen realms). ${ }^{21}$

2) Faith in the Apostle

Rasul means messenger containing the meaning of selected humans who receive revelation from Allah SWT and are tasked with conveying the contents of the revelation (good news and warning (basyîran wa nażîra) to each of his people. Various verses in the Qur'an describe the Apostle, some are told in the Qur'an and some are not told. There are only 25 Apostles mentioned by name in the Qur'an. Regarding the number of Apostles no one knows for sure, although there are scholars who say the total number is 124,000 ( one hundred twenty four thousand) people ${ }^{22}$. But only Allah SWT knows the number. As for those who were appointed as Apostles, 313 people and even this there is a difference of opinion. ${ }^{23}$ The scholars explain the difference between the Prophet and the Apostle. They say that every Apostle must be a Prophet, but not every Prophet is an Apostle.

\footnotetext{
${ }^{19}$ Muhammad bin Shalih Al-Utsamin, Prinsip-prinsip Keimanan, 1 ed. (Riyadh: Haiatul Ighatsah al Islamiah al Alamiah, 1993). H. 26

${ }^{20}$ Abu Ubaidah Darwis, Panduan Akidah Ahlu Sunnah Wal Jamaah, 1 ed. (Jakarta: Pustaka AlKautsar, 2008). H. 137

${ }^{21}$ Zainuddin, Ilmu Tauhid Lengkap, 2 ed. (Jakarta: PT Rineka, 1996). H. 91

${ }^{22}$ Ibnu Katsir, Tafsir Ibnu Katsir Jilid Pertama (Jakarta: Pustaka Imam asy-Syafii, 2008).

${ }^{23}$ Katsir. H. 104
}

Al Qalam: Jurnal Ilmiah Keagamaan dan Kemasyarakatan Vol. 16, No. 2

Maret - April 2022 
The difference between the two is that the Apostle has an obligation to convey the message (revelation) he has received to his people. Meanwhile, the Prophet had no obligation to convey the teachings he received to mankind. ${ }^{24}$

As for the word of Allah SWT relating to His messengers and the appointment of his treatise, which is contained in the QS an-Nahl: 36:

"And verily We have sent a Messenger to every people (to call): "Worship Allah (only), and stay away from Tâgut".

A Muslim believes that Allah SWT has given revelation and sanctified His messengers among humans by assigning him to convey the revelation so that there will be no more excuses for humans later on the Day of Resurrection. Allah SWT sent them with explanations and miracles. They are human beings who cannot be separated from their humanity such as eating, drinking, falling sick, forgetting or remembering and living or dying. They are truly the most perfect human beings without exception. ${ }^{25}$

3) Faith in the Last Day

The discussion about faith in the last day is divided into several parts ${ }^{26}$; first, a discussion of death as the first door to the final world, Second, Faith in the Last Day which discusses events before the Day of Judgment, Third, The chaos of the Day of Judgment which discusses events after the Day of Judgment, starting from the day of resurrection until people are judged and decided to go to hell or go to heaven. Fourth, a discussion of heaven and hell which explains the blessings of heaven and the punishment of hell.

The division of material that is so wide departs from the names of the Day of Judgment as it is well-known to us, namely the Day of Judgment which is also known as Yaumul Akhir (last day), Yaumul Ba'ats (Day of Resurrection), Yaumul Hisâb (Day of Reckoning), Yaumul Jaza. 'i (Day of Judgment), which is retribution for all the deeds of humans while living in this world ${ }^{27}$. Belief and belief in the existence of the Day of Judgment provides a lesson that all living things, especially humans, will experience death and will be resurrected to account for all their deeds in the world.

Doomsday marks the final chapter of the history of human life on earth. The coming of the Day of Judgment cannot be doubted even the process of its occurrence is very clear. For a Muslim, it is obligatory to believe that life in this world is only temporary and will not take long to be revived

\footnotetext{
${ }^{24}$ Darwis, Panduan Akidah Ahlu Sunnah Wal Jamaah. H. 160

${ }^{25}$ Abu Bakar Jabir Al-Jazairi, Pola Hidup Muslim; Aqidah, 2 ed. (Bandung: PT. Remaja Rosdakarya, 1993). H. 53

${ }^{26}$ Wismanto, Kitab Tauhid "Esa-kanlah-Aku."

${ }^{27}$ Wismanto.
}

Al Qalam: Jurnal Ilmiah Keagamaan dan Kemasyarakatan Vol. 16, No. 2

Maret - April 2022 
and brought before Allah SWT. to be responsible for all the actions that have been done while living in the world. ${ }^{28}$ So that by having faith in the Last Day will always remind someone to always increase their worship both in terms of quality and quantity because life in this world is only a temporary life and is not eternal. The eternal life is the afterlife.

4) Faith in Qađa and Qadar

SayQađameans the provisions determined by Allah SWT. While Qadar is the implementation of these provisions. Faith in qađa and qadar provides an understanding that we must believe in the Almighty and Omnipotent of Allah SWT. as the only Essence who has sole authority in lowering and determining any provisions for His creatures. Humans are given the ability and autonomy to determine their own destiny with their efforts and prayers to Allah SWT. ${ }^{29}$ By having faith in qađa and qadar, a person will believe that all events that occur in his life are the provisions of Allah SWT. so he is always optimistic that what happens is a provision from Allah swt. and he will live this life with trust in Allah SWT. by remembering himself that only Allah SWT is the only one who has power over his life. But besides that, Allah SWT. commanded humans to keep trying to do good. In other words, everything that happens and happens is according to His qađa and qadar. This is as confirmed in the Qur'an QS al-Qamar: 49 which means: "Indeed We created everything according to size."

\section{Tawhid Uluhiyyah}

The ijmali (global) meaning of Uluhiyyah monotheism is a unanimous self-denial that Allah SWT is ilâhul Haqq (God who has the right to be worshiped) and there is no other ilâhul Haqq besides Him. ${ }^{30}$ As his servants, we must believe that only Allah SWT is worthy of worship and that there is no god that must be worshiped except Allah SWT. This monotheism is the essence of the mission of the apostles because he is the principle and foundation on which all deeds are built. ${ }^{31}$ The Apostles are messengers of Allah SWT who were given the mandate to teach their people, namely in the form of teaching to unite in Him which is the most important teaching because this monotheism is the essence of faith in Allah SWT. Collecting the monotheism of rubûbiyyah, as well as the monotheism of Asma` and His attributes. ${ }^{32}$

Believing or believing in the ulûhiyah of Allah SWT is by uniting Allah SWT with the actions of the servants based on a sincere intention to get closer to Him in accordance with what

\footnotetext{
${ }^{28}$ Darwis, Panduan Akidah Ahlu Sunnah Wal Jamaah.

${ }^{29}$ Dervish.

${ }^{30}$ Muhammad Na'im Yasin, Iman: Rukun, Hakikat dan yang Membatalkannya, 5 ed. (Jakarta: Gema Insani Press, 1992). H. 24

${ }^{31}$ Al-Fauzan, Kitab Tauhid I. h. 53

${ }^{32}$ Yasin, Iman: Rukun, Hakikat dan yang Membatalkannya. H. 25
}

Al Qalam: Jurnal Ilmiah Keagamaan dan Kemasyarakatan Vol. 16, No. 2

Maret - April 2022 
has been prescribed. In very simple language, it can be said that believing in the ulûhiyah of Allah SWT is making Allah SWT the sole target (goal) in carrying out various ubûdiyyah activities. ${ }^{33}$ Because all forms of worship that we do must be based on intentions solely for Allah SWT and not the least bit polluted by other intentions.

From the description above, it can be understood that monotheism ulûhiyah is the belief that Allah SWT is the only God who must be worshiped and has no partners for him. This ulûhiyah monotheism is the core of the other monotheisms, namely the monotheism of the rubûbiyyah and the monotheism of asmâ` wa character. As for what is included in this ulhiyah monotheism are all matters concerning the worship of Allah which have been explained through the Shari'a brought by the Prophet Muhammad. It includes prayer, fasting, zakat, pilgrimage and so on. ${ }^{34}$

\section{Tawhid Asma Wa Sifat}

Faith in the names and attributes of Allah SWT, namely determining the names and attributes that Allah SWT has determined for Himself in His holy book or the sunnah of His Messenger in a way that is in accordance with His greatness without tahrif (deviation). , ta'ţil (removal), takyif (asking how?), and tamśil (likening). ${ }^{35}$

The understanding of this monotheism is that the monotheism of Asma and nature is based on three principles, namely:

a. Purify and exalt Allah SWT from things that resemble Him with creatures, or from a deficiency. So monotheism in its nature is self-denial unanimously to acknowledge that Allah SWT ordered to purify Him, He is clean from wife, partner, there is no comparison in common, there is no intercession (without Allah's permission).

b. Faith in asthma and the attributes that have been stipulated in the Book of Allah and the Hadith of the Prophet, without limiting it by reducing or adding or turning away even in the slightest, or ignoring/assuming that there is nothing to these stipulations.

c. Throwing away the (excessive) imagination to visualize these qualities, that is, it is required for the Mukmin (servant) who is mukallaf to believe in the qualities and names whose texts are clearly stated in the Book of Allah and the Sunnah of the Messenger of Allah, without the need to discuss or question the visualization. This is because the attributes of Allah SWT are completely different from those of the creatures He created, which generally require proof both materially and visually. ${ }^{36}$

Tawhid asma wa characterthis is monotheism in purifying Allah from things that can pollute

\footnotetext{
${ }^{33}$ Darwis, Panduan Akidah Ahlu Sunnah Wal Jamaah. H. 49

${ }^{34}$ Wismanto, Kitab Tauhid "Esa-kanlah-Aku."

35 Al-Utsamin, Prinsip-prinsip Keimanan. H. 30

${ }^{36}$ Yasin, Iman: Rukun, Hakikat dan yang Membatalkannya. H. 35
}

Al Qalam: Jurnal Ilmiah Keagamaan dan Kemasyarakatan Vol. 16, No. 2

Maret - April 2022 
one's faith. Because we have been convinced that it is Allah who only has the nature of perfection, who is clean from allies, as is the understanding held by the people of the trinity that Allah SWT has children. Even though it is clear in the Qur'an that Allah SWT does not have children and is not begotten.

Here it can be understood that Allah SWT is the only God who must be believed and worshiped, a believer is required to believe in the Oneness of Allah SWT in worship, the power of Allah SWT in His creation. Humans are only ordered to think about His creation but are not commanded to think about the essence of Allah SWT. Faith in monotheism asmâ' wa character includes faith in the book of Allah SWT because one of the obligatory attributes for Allah SWT is the nature of Kalam, and the book of Allah SWT is kalamullah. In addition, a believer is required to believe in the qualities or names whose texts are clearly mentioned in the Qur'an. While what is meant by believing in Allah's books, it means that we must also believe that Allah SWT has sent down several books to His Prophets.

Muslims are people who believe in the books revealed by Allah SWT and revealed to His messengers. These books are the words of Allah SWT revealed by Allah SWT to His prophets and messengers so that they convey the Shari'ah and His religion. This greatest book is fourfold: First, the Qur'an al-Karim which was revealed to Muhammad, second, the Torah which was revealed to the Prophet Musa as., the third Zabur which was revealed to Prophet Dawud as., Fourth, the Gospel which was revealed to the Prophet Jesus as. Among the four, the Qur'an is the most perfect book. He is the complement of the Shari'ah and the laws of the other books. ${ }^{37}$ This is based on the word of Allah SWT in Surah Annisa 136 which means: "O you who believe, keep believing in Allah and His Messenger and in the book that Allah sent down to His Messenger and the book that Allah sent down before."

\section{Youth in Islamic Literature}

1. The Story of Prophet Ibrahim as a Youth

Prophet Abraham as. Teaching mankind to uphold monotheism, namely worshiping only Allah SWT, and staying away from shirk, namely worshiping other gods besides Allah, such as stars, sun, moon, statues, and others. Prophet Abraham as. has left us about how the educational process should be carried out. Starting from the main materials to the method or method of delivery. Prophet Abraham's success. In shaping the pious personality of the Prophet Ismail as. and Prophet Ishaq as., the fortitude of Siti Hajar and Sarah, and the many prophets from the descendants of Prophet Abraham. is proof of the success of education carried out by Prophet Ibrahim as.

\footnotetext{
${ }^{37}$ Al-Jazairi, Aqidah Seorang Mukmin. H. 39
}

Al Qalam: Jurnal Ilmiah Keagamaan dan Kemasyarakatan Vol. 16, No. 2

Maret - April 2022 
A scholar, At-Tabari said that there had never been a young man who had insulted their idol at that time apart from that young man named Ibrahim. This is as said by Ibn Kathir ${ }^{38}$ as follows:

$$
\text { الله اً لا اباً لا العلم الم لا اب، لا الآيتةالُو ا الُ لَهُ اهِيم : }
$$

"Allah did not send a prophet except a youth, nor was he given extensive knowledge unless he was a young man." Then read the letter al-Anbiya verse 60 which means: They said: "We heard there was a young man who denounced these idols named Ibrahim".

2. The story of the Prophet Yusuf as a Youth

The story of another exemplary youth in the Qur'an is the story of the Prophet Yusuf (as), when his faith was tested by the seduction of beautiful and noble women, Yusuf was not carried away and fell into his lust, with the strength of his faith and monotheism in Allah SWT, Yusuf easily got through the test of faith as Allah SWT proclaims in the Qur'an Surah Yusuf verse 30:

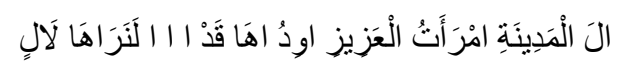

"And the women in the city said: "Al Aziz's wife tempts his bachelor to submit himself (to him), in fact his love for his bachelor is very deep. Indeed, we see him in clear error."

The great power of monotheism in Yusuf (as) encouraged him to remain introspective and dare to act according to the truth of reason and the call of conscience. Strong understanding and belief in monotheism makes a person without hesitation to do everything that Allah SWT commands, and lightheartedly stay away from everything that Allah SWT forbids to do.

3. The Story of the Youth of Ashabul Kahfi

The story of the Ashabul Kahf youths in the Qur'an is a miracle that happened to the youths who held fast to their monotheistic beliefs. Belief in Allah SWT, the only one who has the right to be worshiped and exalted, has resulted in them having to isolate themselves from society and their environment who make other gods besides Allah SWT. The understanding of the values of monotheism gave birth to the firmness of faith and belief in Allah SWT, so that because of this strong belief Allah SWT provided help and facilitated all their affairs, as the word of Allah SWT in Surah al-Kahf verse 13:

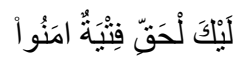

"We tell you (Muhammad) this story correctly. Verily, they are youths who believe in their Lord, and We also added for them guidance."

${ }^{38}$ Katsir, Tafsir Ibnu Katsir Jilid Pertama.

Al Qalam: Jurnal Ilmiah Keagamaan dan Kemasyarakatan Vol. 16, No. 2

Maret - April 2022 
Imam Ibn Kathir said that the people involved in the story of Ashabul Kahf were young men who were firm in their stance and monotheism, with a youth character full of enthusiasm and optimism, these youths chose to get out of their comfort zone and isolate themselves from the community for fear of their monotheism would eroded due to the threat and pressure of the majority of society. The value that can be drawn from the story of Ashabul Kahf for youth is the urgency of the values of monotheism that must be instilled in young people from an early age so that these values are embedded from an early age and make monotheism the basis for all actions taken.

Tawhid material is the main curriculum in Islamic youth education, the verses of the Qur'an and the explanations of the scholars very clearly emphasize the urgency of monotheism education in Islamic youth education. A straight understanding of monotheism will make a Muslim youth have a consistent fighting spirit, because with a straight understanding of monotheism, all conditions that befall a Muslim youth, good and bad, difficult and happy, will always be weighed based on the understanding of monotheism, that is, everything will have value. worship if the response is in accordance with the rules of monotheism.

\section{CONCLUSION}

Islamic education, as part of the Islamic institutional structure, is very interested in functioning and actualizing the values of monotheism in the educational process. At the curriculum level, the values of monotheism can be the basis in formulating the basic principles that Islamic educational institutions want to build. Therefore, the Islamic youth education curriculum must be oriented to the development of divine (theological), natural and human values. This also makes the prophets become young people who are very resistant to various things that can cause damage to their faith. The story of Prophet Ibrahim, Prophet Yusuf,

\section{BIBLIOGRAPHY}

Al-Buraikan, Ibrahim bin Muhammad. Pengantar Studi Aqidah Islam. 1 ed. Jakarta: Robbani Press, 1998.

Al-Fauzan, Shalih bin Fauzan. Kitab Tauhid I. 1 ed. Jakarta: Darul Haq, 2011.

Al-Jazairi, Abu Bakar Jabir. Aqidah Seorang Mukmin. 1 ed. Solo: CV. Pustaka Mantiq, 1994. . Pola Hidup Muslim; Aqidah. 2 ed. Bandung: PT. Remaja Rosdakarya, 1993.

Al-Utsamin, Muhammad bin Shalih. Prinsip-prinsip Keimanan. 1 ed. Riyadh: Haiatul Ighatsah al Islamiah al Alamiah, 1993.

Baqi, Muhammad Fuad Abdul. al-Mu'jam al-Mufahras li Alfadz al-Qur'an al-Karim. Cairo: Daar alHadists, 2001.

Al Qalam: Jurnal Ilmiah Keagamaan dan Kemasyarakatan Vol. 16, No. 2

Maret - April 2022 
Dalimunthe, Sultani. "Metode Kisah dalam Perspektif al-Qur'an.” Jurnal Tarbiyah 23, no. 2 (2016): 276.

Darwis, Abu Ubaidah. Panduan Akidah Ahlu Sunnah Wal Jamaah. 1 ed. Jakarta: Pustaka Al-Kautsar, 2008.

Katsir, Ibnu. Tafsir Ibnu Katsir Jilid Pertama. Jakarta: Pustaka Imam asy-Syafii, 2008.

Madjrie, Abdurrahman. Meluruskan Akidah. 1 ed. Yogyakarta: Titian Ilahi Press, 1997.

Nursi, Badiuzzaman Said. Iman Kunci Kesempurnaan. Terjemahan dari AlIman wa Takamulul Insan. 1 ed. Jakarta: Robbani Press, 2004.

Sugiyono. Metode Penelitian Kuantitatif, Kualitatif dan R and D. 22 ed. Bandung: Alfabeta, 2016.

Sukmadinata, Nana Syaodih. Pengembangan Kurikulum. Bandung, 1996.

Tafsir, Ahmad. Ilmu Pendidikan Dalam Perspektif Islam. Bandung: Remaja Rosdakarya, 2012.

Umar, Bukhari. Ilmu Pendidikan Islam. Jakarta: Amzah, 2010.

Wismanto, Abu Hasan. Kitab Tauhid "Esa-kanlah-Aku." Pemalang: Nasya Expanding Manajemen, 2016.

Yasin, A. Fatah. Dimensi-dimensi Pendidikan Islam. Malang: UIN Malang Press, 2008.

Yasin, Muhammad Na'im. Iman: Rukun, Hakikat dan yang Membatalkannya. 5 ed. Jakarta: Gema Insani Press, 1992.

Yusuf, A Muri. Metode Penelitian Kuantitatif, Kualitatif dan Penelitian Gabungan. 4 ed. Jakarta: Kencana, 2017.

Zainuddin. Ilmu Tauhid Lengkap. 2 ed. Jakarta: PT Rineka, 1996.

Al Qalam: Jurnal Ilmiah Keagamaan dan Kemasyarakatan Vol. 16, No. 2

Maret - April 2022 